\title{
PENGARUH PERBEDAAN KECEPATAN PUTARAN MESIN (RPM) TERHADAP KINERJA MESIN PENCACAH LIMBAH JAGUNG UNTUK PAKAN TERNAK SAPI DI NUSA TENGGARA TIMUR
}

\author{
Umbu A Hamakonda ${ }^{1}$, Edelnia Bere ${ }^{2}$, Muhamad Muhdin ${ }^{1}$, dan Fatu L Lalus ${ }^{3}$ \\ ${ }^{1}$ Program Studi Agroteknologi, Sekolah Tinggi Pertanian Flores Bajawa (STIPER FB) NTT \\ 2 Program Studi Peternakan Sekolah Tinggi Pertanian Flores Bajawa (STIPER FB) NTT \\ ${ }^{3}$ Program studi Keteknikan Pertanian Fakultas Teknologi Pertanian Unkris Kupang \\ Email: umbu_hamakonda@yahoo.com
}

\begin{abstract}
ABSTRAK
Penelitian ini bertujuan untuk mengetahui pengaruh kecepatan putaran mesin pencacah terhadap kualitas hasil cacahan dan menentukan kecepatan putaran mesin dengan hasil cacahan yang berkualitas. Metode yang digunakan dalam penelitian ini adalah metode ekperimental untuk menganalisis ragam pengaruh perlakuan terhadap pengaruh perbedaan kecepatan putaran mesin. Dengan metode ini dapat menganalisis dan diketahui perlakuan terbaik. Hasil penelitian menunjukkan bahwa kapasitas kerja tertinggi terdapat pada RPM 3400 sebesar 13,11 gr/menit yang berbeda nyata dengan perlakuan lainnya. Kapasitas kerja alat terbaik terdapat pada perlakuan C dengan nilai rata rata sebesar 5,43 gram/menit. Hasil uji jarak berganda duncan terhadap keseragaman hasil cacahan menunjukkan bahwa pada pada kecepatan putaran $3400 \mathrm{rpm}$ menghasilkan ukuran cacahan terbaik dengan ukuran $2 \mathrm{~cm}$ paling besar yaitu sebanyak 5,43 gram, yang berbeda nyata dengan kecepatan putaran mesin lainnya.

Kata kunci-limbah jagung; mesin pencacah; kapasitas kerja alat; keseragaman cacahan
\end{abstract}

\section{PENDAHULUAN}

Penanaman jagung secara intensif selain menghasilkan bobot biji yang tinggi juga menyisakan limbah dalam bentuk batang, daun, klobot, dan janggel. Limbah tersebut memiliki potensi cukup tinggi limbah pertanaman jagung pada umumnya tidak dikembalikan lagi ke lahan atau dibakar karena mengganggu pengelolaan lahan pertanaman berikutnya. Sebenarnya limbah tanaman jagung dapat menjadi bahan baku untuk pembuatan pupuk organik, karena limbah jagung mengandung selulosa, hemi selulosa, maupun lignin sebagai penyusun utama serasah tanaman (Herdiyantoro, 2010).

Produksi kompos komersil yang terbuat dari limbah pertanian adalah pilihan yang aman sebagai pembenah tanah secara alami dibanding pupuk kimia (Al Barkah., $d k k$ 2013). Cara yang dapat dilakukan untuk menangani limbah tersebut yaitu dengan cara mencacah atau mengecilkan ukuran limbah agar dapat dimanfaatkan menjadi pupuk organik. Apabila proses pencacahan dilakukan dengan cara manual akan membutuhkan waktu yang lama sehingga tidak efisien. Oleh karena itu diperlukan aplikasi teknologi alat pengecil ukuran (mesin pencacah) untuk memudahkan dan mempercepat proses pencacahan dan pemanfaatan limbah.

Salah satu mesin pencacah yang ada dipasaran adalah mesin pencacah jerami jagung. Mesin pencacah yang akan digunakan pada penelitian ini yaitu mesin pencacah jerami jagung yang mempunyai fungsi untuk mencacah rumput hijauan,batang dan daun jagung, penepung tongkol jagung, jerami padi dan banyak lagi yang bisa dicacah menggunakan alat pencacah ini. Penggunaan alat mesin pencacah ini sudah banyak digunakan oleh masyarakat umum. Akan tetapi masih menimbulkan berbagai permasalahan mengenai alat tersebut. Salah satu faktor timbulnya permasalahan ini yaitu karena tingkat keberagaman jenis bahan yang akan dicacah dan kurangnya pemahaman masyarakat mengenai karakter ristik kinerja suatu mesin tersebut. Sehingga hasil kinerja suatu alat pencacah tersebut tidak bekerja dengan maksimal. Hal ini terjadi dikarenakan alat tersebut tidak bekerja sesuai dengan kemampuan spesifikasinya. Pencacahan manual dilakukan dengan menggunakan tenaga manusia.Pencacahan dilakukan dengan menggunakan pisau sampai bahan yang dicacah menjadi lebih kecil dan halus (Sofian, 2010).

Kualitas kompos ditentukan oleh aktivitas mikrobia pada proses pengomposan dan aktivitas mikroba dipengaruhi oleh beberapa faktor yaitu: bahan baku, komposisi nutrisi, kelembaban, temperatur, keasaman atau kegaraman, dan aerasi (Anyanwu, $d k k$., 2013). Menurut Ogbonna, $d k k$. 
(2012) bahwa aplikasi kompos limbah organik ke lahan pertanaman jagung pada tanah Ultisol memperbaiki sifat fisik tanah, meningkatkan kandungan hara $\mathrm{N}, \mathrm{P}$, dan $\mathrm{K}$, serta beberapa hara mikro seperti: Zn, Fe, dan Cu. Sementara (Azis, 2014) menyatakan bahwa manfaat aplikasi kompos ke lahan pertanian yaitu meningkatkan produktivitas, memperbaiki biodiversity tanah, mengurangi resiko ekologi, dan memperbaiki lingkungan.

Kurangnya pemahaman masyarakat mengenai karakteristik mesin pencacah yaitu, terkait dengan tingkatan kecepatan putaran mesin (RPM) dimana masyarakat mengoperasikan mesin pencacah menggunakan kecepatan putar mesin dengan cara seadanya. Padahal kecepatan putar akan mempengaruhi hasil dari kapasitas cacahan, bahan bakar yang akan terpakai, dan ukuran hasil cacahan.Oleh karena itu, maka perlu dilakukannya penelitian ini untuk pengujian kecepatan putaran pada mesin pencacah jerami jagung dengan bahan uji batang dan daun jagung sebagai bahan baku pembuat pupuk kompos, terutama terkait dengan kecepatan putar (RPM) mesin. Tujuan dari penelitian ini adalah mengetahui pengaruh kecepatan putaran mesin pencacah jerami jagung terhadap kualitas hasil cacahan batang dan daun jagung dan menentukan kecepatan putaran mesin berapa yang dapat mencacah hasil cacahan yang berkualitas.

\section{METODOLOGI PENELITIAN}

\section{A. Alat dan Bahan}

Bahan yang digunakan dalam penelitian ini adalah batang jagung yang dijadikan sebagai bahan dasar dalam melakukan pembuatan kompos maupun pakan ternak dan bahan bakar premium (bensin). Alat yang digunakan dalam penelitian ini adalah satu unit mesin pencacah, stop watch, terpal, tacho meter, timbangan analitik, dan alat pendukung lainnya.

\section{B. Pelaksanaan Penelitian}

Pelaksanaan pada penelitian ini yaitu dimulai persiapan alat dilakukan dengan melakukan pengecekan mesin pencacah jerami jagung diantaranya pengecekan motor penggerak, pisau pemotong, lubang masukan bahan (input), lubang keluaran bahan (Output). Persiapan alat bertujuan untuk memastikan mesin bekerja optimal sebelum dilakukan pengukuran. Persiapan alat pembantu pengukuran diantaranya stop watch sebagai alat mengukur waktu kecepatan kerja mesin, timbangan analitik, karung plastik atau kantung plastik. Persiapan bahan dilakukan dengan mempersiapkan bahan-bahan yang akan dicacah, bahan berupa limbah jagung dan bahan bakar (bensin).

\section{Rancangan Percobaan}

Penelitian ini menggunakan metode rancangan acak lengkap ( RAL ) dengan 3 kali perlakuan dan 9 kali ulangan sehingga di peroleh 27 unit percobaan. Perlakuan yang di teliti terdiri dari: perlakuan $\mathrm{A}=1100 \mathrm{rpm}$, perlakuan $\mathrm{B}=2250 \mathrm{rpm}$, dan perlakuan $\mathrm{C}=3400 \mathrm{rpm}$. Perlakuan terbaik dalam penelitian ini adalah kemampuan mesin pencacah untuk menghasilkan cacahan yang sesuai standar.

\section{Pengamatan dan Analisis Data}

1. Kapasitas kerja alat (gr/menit)

Kapasitas kerja pencacahan dihitung dengan cara menimbang bahan hasil cacahannya dalam waktu yang telah ditentukan yaitu selama 1 menit. Adapun rumus untuk menghitung kapasitas pencacahan yaitu:

$K K a=\frac{B K}{t} \times 100 \%$

keterangan:

$\mathrm{Kka}=$ kapasitas pencacahan (gr/menit)

$\mathrm{Bk}=$ berat hasil cacahan $(\mathrm{gr})$

$\mathrm{t} \quad=$ waktu pencacahan bahan.

2. Keseragaman hasil cacahan (gr)

Cacahan yang dihasilkan ditimbang secara keseluruhan. Kemudian dilakukan proses pengelompokan hasil cacahan berdasarkan ukurannya. Ukuran hasil cacahan adalah 2, 5, dan $12 \mathrm{~cm}$ 
sesuai dengan tentang ( SNI 19:7030,2004 ). Panjang potongan limbah jagung dari mesin akan menghasilkan cacahan limbah jagung dengan ukuran kecil atau halus dengan demikian akan muda terurai maka proses pengomposan semakin cepat. Rumus untuk menghitung keseragaman hasil cacahan sebagai berikut:

$\mathrm{KHC}=\frac{H C_{1}}{H C_{0}} \times 100 \%$

keterangan:

$\mathrm{KHC}=$ keseragaman hasil cacahan $(\%)$

$\mathrm{HC}_{1}=$ berat hasil cacahan sesuai dengan ukuran perlakuan (gram)

$\mathrm{HC}_{0}=$ berat awal bahan sebelum dicacah (gram)

\section{Analisis Data}

Analisis data yang digunakan adalah analisis ragam anova untuk mengetahui kemampuan mesin dalam menghasilkan cacahan yang terbaik dan kapasitas kerja alat tertinggi.

\section{HASIL DAN PEMBAHASAN}

\section{A. Kapasitas Kerja Alat}

Hasil analisis sidik ragam (Anova) terhadap kapasitas kerja alat menunjukan bahwa perlakuan kecepatan putar mesin berpengaruh nyata terhadap kapasitas kerja alat dengan tinggkat kepercayaan 99\%. Pada hasil uji dengan tingkat kepercayaan 99\%. Hasil uji jarak berganda duncan dapat disajikan pada Tabel 1.

Tabel 1. Rata - rata Perlakuan Kapasitas Kerja Alat

\begin{tabular}{cc}
\hline Perlakuan & Rata - rata $(\mathrm{gr} /$ menit $)$ \\
\hline Perlakuan $\mathrm{A}=1200$ & $8.38^{\mathrm{b}}$ \\
Perlakuan $\mathrm{B}=2250$ & $9.82^{\mathrm{a}}$ \\
Perlakuan $\mathrm{C}=3400$ & $13.11^{\mathrm{a}}$ \\
\hline
\end{tabular}

Berdasarkan Tabel 1 menunjukkan bahwa perlakuan C (3400 rpm) menunjukan kapasitas kerja alat tertinggi 13.11 gram/menit,yang berbeda nyata dengan perlakuan lainnya. Sedangkan perlakuan B (2250 rpm) menunjukan kapasitas kerja alat tertinggi ke kedua dengan hasil 9.82 gram/menit, yang berbeda nyata dengan perlakuan lainnya dan kapasitas kerja alat terendah terdapat pada perlakuan A (1200 rpm) dengan hasil 8.38 gram/menit,yang berbeda nyata dengan perlakuan lainnya ( C ) dan perlakuan B berbeda nyata dengan perlakuan (A). Merujuk dari hukum newton II maka makin besar gaya yang diterima, maka percepatan makin besar. Selanjutnya menurut mathematica Tahun 1687 tentang hukum newton II menyatakan bahwa sebuah benda dengan massa mengalami gaya resultan sebesar gaya akan mengalami percepatan dengan gaya yang sama dengan arah gaya dan besar berbanding lurus terhadap gaya suatu benda.

\section{B. Hasil Keseragman Cacahan}

Keseragaman cacahan adalah keluaran yang mempunyai ukuran sama. Keseragaman hasil cacahan perlakuan $2 \mathrm{~cm}$ disajikan pada Table 2, perlakuan $5 \mathrm{~cm}$ pada Tabel 3 , dan perlakuan $12 \mathrm{~cm}$ pada Tabel 4.

Tabel 2. Kesergaman Hasil Cacahan $(2 \mathrm{~cm})$

\begin{tabular}{cc}
\hline Perlakuan & Rata - rata $(\%)$ \\
\hline Perlakuan $A=1200$ & 33.20 \\
Perlakuan B $=2250$ & 41.30 \\
Perlakuan C $=3400$ & 53.40 \\
\hline
\end{tabular}

Hasil uji jarak berganda duncan pada perlakuan C (3400 rpm) dapat menghasilkan hasil cacahan $2 \mathrm{~cm}$ (Tabel 2) terbanyak yaitu 53.40\% yang berbeda nyata dari perlakuan lainnya (A dan B ). Sedangkan perlakuan B (2250 rpm) dapat menghasilkan cacahan $2 \mathrm{~cm}$ sebanyak $41.30 \%$ gram yang berbeda nyata dengan perlakuan $\mathrm{C}$ dan tidak ada perbedaan nyata dengan perlakuan lainnya $\mathrm{A}$. 
Perlakuan A (1200 rpm) dapat menghasilkan cacahan $2 \mathrm{~cm}$ sebanyak $33.20 \%$ yang berbeda nyata dengan perlakuan $\mathrm{C}$ dan tidak ada perbedaan nyata dengan perlakuan B. Sehinga total cacahan $2 \mathrm{~cm}$ sebanyak 12,88 gram. Jadi dari hasil ini menunjukkan bahwa perlakuan terbaik terdapat pada perlakuan $\mathrm{C}$ yang dapat menghasilkan cacahan terbaik $2 \mathrm{~cm}$ sebagai bahan untuk pembuatan pupuk kompos.

Tabel 3 Keseragaman Hasil Cacahan $5 \mathrm{~cm}$

\begin{tabular}{cc}
\hline Perlakuan & Rata - rata $(\%)$ \\
\hline Perlakuan $\mathrm{A}=1200$ & 36.30 \\
Perlakuan $\mathrm{B}=2250$ & 30.70 \\
Perlakuan $\mathrm{C}=3400$ & 36.30 \\
\hline
\end{tabular}

Hasil uji jarak berganda duncan pada perlakuan C (3400 rpm) dapat menghasilkan cacahan 5 $\mathrm{cm}$ (Tabel 3) sebesar $36.30 \%$ tidak ada perbedaan nyata dengan perlakuan lainnya (A dan B). Sedangkan perlakuan B ( $2250 \mathrm{rpm}$ ) dapat menghasilkan cacahan $5 \mathrm{~cm}$ sebanyak $30.70 \%$ tidak ada perbedaan nyata dengan perlakuan lainnya (C dan A) dan perlakuan A ( $1200 \mathrm{rpm}$ ) dapat menghasilkan cacahan $5 \mathrm{~cm}$ sebanyak 2,83 gram tidak ada perbedaan nyata dengan perlakuan (B dan C). Sehingga total hasil caachan $5 \mathrm{~cm}$ sebanyak 9,53 gram. Jadi dari hasil ini menunjukkan bahwa perlakuan terbaik yang dapat menghasilkan cacahan $5 \mathrm{~cm}$ terbanyak terdapat pada perlakuan C (3400 rpm) dengan hasil cacahan $36.30 \%$ sebagai bahan untuk pembuatan pupuk kompos. Jadi Hasil analisis data persentase keseragaman menunjukan perlakuan keseragaman terhadap hasil cacahan tidak berpengaruh nyata terhadap persentase hasil cacahan.

Tabel 4. Keseragaman Cacahan $12(\mathrm{~cm})$

\begin{tabular}{cc}
\hline Perlakuan & Rata - rata $($ gram $)$ \\
\hline Perlakuan A $=1200$ & 23.80 \\
Perlakuan B $=2250$ & 26.00 \\
Perlakuan C $=3400$ & 40.50 \\
\hline
\end{tabular}

Hasil uji jarak berganda duncan menunjukkan bahwa keseragaman $12 \mathrm{~cm}$ (Tabel 4) tertinggi terdapat pada perlakuan C (3400 $\mathrm{rpm})$ sebesar $40.50 \%$ yang berbeda nyata dengan perlakuan lainnya (B dan A). Sedangkan keseragaman hasil cacahan tertinggi ke dua terdapat pada perlakuan B (2250 rpm) sebesar $26.00 \%$ yang berbeda nyata dengan perlakuan $\mathrm{C}$ dan tidak ada perbedaan nyata dengan perlakuan lainnya dan perlakuan A. Pada perlakuan A (1200 rpm) menghasilkan hasil keseragaman cacahan terendah sebanyak $23.80 \%$ yang berbeda nyata dengan perlakuan $\mathrm{C}$ dan tidak ada perbedaaan nyata dengan perlakuan B. Sehinga total hasil cacahan $12 \mathrm{~cm}$ sebanyak 9,05 gram. Sehingga hasil penelitian menunjukkan bahwa pada perlakuan terbaik terdapat pada perlakuan C (3400 rpm ) yang dapat menghasilkan hasil cacahan $12 \mathrm{~cm}$ terbanyak dari perlakuan yang lainya.

\section{KESIMPULAN}

Dari hasil penelitian yang telah dilakukan dapat disimpulkan bahwa kecepatan putaran (RPM) sebesar $3400 \mathrm{rpm}$ menghasilkan cacahan terbanyak yaitu $13.11 \mathrm{gram} / \mathrm{menit}$ dan menghasilkan ukuran cacahan terbaik dengan ukuran $2 \mathrm{~cm}$ paling besar yaitu 5,43 gram.

\section{DAFTAR PUSTAKA}

Al Barkah, FN.,S.M.A. Radwan and R.A.A. Aziz. 2013. Using Biotechnology in recycling agricultural waste for sustanaible agriculture and environment protection. Int J. of Current Microbial and Appl. Sci. 2(12): 446-459.

Anyanwu, C.F., S.L. Ngohayon, R.L. Ildefonso, J.L. Algohayon. 2013. Application of Indegeneus Microorganism (IMO) for bio conservation of Agricultural waste. International Journal of Science and Research (IJSR) 4(5):778-784. 
Azis, A.R.A., 2014. Composting technology and impact of compost on arid soil biochemical properties. Int. J. Plant and Soil Science 3(6): 538-553.

Herdiyantoro, 2010. Pengomposan: Mikrobiologi dan Teknik Pengomposan. Laboratorium Biologi dan Bioteknologi Tanah. Jurusan Ilmu Tanah. Fakultas Pertanian Universitas Padjadjaran.

Ogbonna, D.N., N.O. Isirimah, and E. Princewill, 2012. Effect of organic waste kompost and microbial activity on the growth of maize in the ultisol in Port Harcourt. Nigeria. African Journal of Biotechnology 11(62): 12546-12554.

Sofian. 2010. Sukses Membuat Kompos dari Sampah. Agromedia Pustaka,Jakarta.

SNI 19:7030,2004 tentang standar ukuran hasil cacahan limbah jagung untuk bahan pembuatan kompos adalah $2-5 \mathrm{~cm}$. 